\title{
LOYALTY TO COMMUNITY MODELING THROUGH VALUE CO-CREATION BEHAVIOR ACTIVITIES WITH PERCEIVED BENEFIT MEDIATION: ORGANIC FOOD PRODUCT
}

\author{
Maya Maria $^{* 1}$, Ujang Sumarwan ${ }^{* *}$, Ahmad Sulaeman $^{* * *}$, Agus W. Soehadi ${ }^{* * * *}$ \\ ${ }^{*}$ Faculty of Economics, Universitas Terbuka \\ Jl. Cabe Raya, Pondok Cabe, Pamulang, Tangerang Selatan 15418, Indonesia \\ ${ }^{* *}$ Departement of Consumer and Family, Faculty of Human Ecology, IPB University \\ Jl. Kamper, Dramaga Campus, IPB University, Bogor 16680, Indonesia \\ ${ }^{* * *)}$ Department of Community Nutrition, Faculty of Human Ecology, IPB University \\ J1. Kamper, Dramaga Campus, IPB University, Bogor 16680, Indonesia \\ ${ }^{* * * *)}$ Faculty of Economics and Business, Universitas Prasetiya Mulya \\ Jl. R.A. Kartini, Cilandak, Jakarta 12430, Indonesia
}

\begin{abstract}
The current trend of people's lifestyles is to start consuming foods that are safe and environmentally friendly. The development of information on the usefulness of organic products more broadly becomes necessary. This study aims to determine the impact of value co-creation activities on loyalty to community, mediated by perceived benefit value. The analysis tool used in this study is Structural Equation Model (SEM) analysis. The sampling method used is a convenience sampling approach with 385 respondents. The results show that consumer perceived benefits value have a strong effect on loyalty to the community. In addition, value co-creation activities in the community is shown to be measurable by customer participation behavior and customer citizenship behavior to obtain the desired perceived benefits. The role of the community with the support of the loyalty of its members can be an effective means of disseminating knowledge about organic food products more broadly to the public. Having these results, the recommended policy direction is to increase the perceived benefits of customer community participation and citizenship. Further studies are needed to refine and build a more comprehensive model that integrates other theoretically related constructs.
\end{abstract}

Keywords: customer participation behavior, customer citizenship behavior, loyalty to community, organic food products, perceived benefit

\begin{abstract}
Abstrak: Adanya tren gaya hidup masyarakat saat ini yang mulai mengkonsumsi makanan yang aman bagi kesehatan dan ramah lingkungan. Pengembangan informasi kebermanfaatan produk organik secara lebih meluas menjadi diperlukan. Penelitian ini bertujuan melihat dampak aktivitas penciptaan nilai bersama (value co-creation), terhadap loyalitas kepada komunitas yang dimediasi oleh manfaat yang dirasakan (perceived benefit values). Alat analisis penelitian ini menggunakan Structural Equation Model (SEM). Metode pengambilan contoh yang digunakan adalah pendekatan convenience sampling dengan jumlah responden sebanyak 385 responden. Hasil menunjukkan bahwa perceived benefit values terbukti berpengaruh kuat terhadap loyalitas pada komunitas. Selain itu aktifitas value co-creation pada komunitas terbukti dapat diukur dengan consumer participation behavior dan consumer citizenship behavior untuk mendapatkan perceived benefit value yang diinginkan. Peran komunitas dengan dukungan loyalitas anggotanya dapat menjadi sarana yang efektif dalam menyampaikan pengetahuan tentang produk pangan organik secara lebih luas kepada masyarakat. Dengan hasil tersebut, maka arahan kebijakan yang direkomendasikan adalah meningkatkan persepsi kemanfaatan dari partisipasi dan keanggotaan komunitas konsumen. Studi lebih lanjut diperlukan untukmenyempurnakan dan membangun model yang lebih komprehensif yang mengintegrasikan pendekatan teoritis dan konstruksi lainnya.
\end{abstract}

Kata kunci: customer participation behavior, customer citizenship behavior, loyalty to community, organic food products, perceived benefit

${ }^{1}$ Corresponding author:

Email: maya.maria.ut2014@gmail.com 


\section{INTRODUCTION}

A healthy and environmentally friendly lifestyle is a new trend and has been institutionalized internationally, which requires guarantees that agricultural products must be safe for consumption (food safety attribute), high in nutritional content (nutritional attribute), and environmentally friendly (eco-labelling attribute). Most overseas consumers prefer food ingredients that are safe for consumption and encourage increased demand for organic products (Mayrowani, 2012). In terms of production, Indonesia has great potential to produce organic food products due to the high availability land for organic farming (Mayrowani, 2012). However, there are various problems from the consumption side, such as market constraints, consumer interest, and the relatively high-cost certification of organic products which causes the market price of organic food products to be expensive (Mayrowani, 2012; Hubeis et al. 2015). Indonesia's organic market is still experiencing obstacles, including being limited to the upper-middleclass economy in urban areas (Nurhidayati et al. 2008), limited to age, education level, and certain income brackets (Slamet et al. 2016), lack of promotional activities and slow increase in promotion and lacking in qualified human resources (Hubeis et al. 2015; Sulaeman in Astuti et al. 2016). Organic food products are not widely known by the public (Muzayanah et al. 2015), because they are more expensive than conventional food products, which may not affect the awareness of some members of the public in implementing a healthy lifestyle and quality diet by consuming organic food products without chemical additives (Chrysanthini et al. 2017; Khorniawati, 2014).

Until 2020 the organic share in Indonesia, which fulfilled, only reached $0.4 \%$ of all agricultural products (Willer et al. 2021). Although organic food has good prospects in the Indonesian market, the actual growth is still relatively low compared to their potential (Najib et al. 2020). The market share of organic food is still very small compared to conventional products (Najib et al. 2020). The obstacles to marketing organic food in Indonesia are purchase resistance of organic foods and consumer confidence (Muzayanah, 2015; Noorjannah, 2012). This study focuses on the constraint of limited information about organic products so that efforts are needed to increase awareness to the public and expand the market for organic products. Need broader consumer education is carried out to change consumer behavior towards organic food (Muzayanah, 2015). Therefore, it is important to study how to increase the number of organic products consumers related to food security issues, especially food safety. Marketing approach in the context of the community as one solution to answer these problems. Spreading information on the use of organic products related to health and environmental issues through communities is expected to be an effective means to indirectly disseminate this information to the public.

This research offers a specific and in-depth study of the value co-creation behavior activity model that affects consumer loyalty to the organic food communities. This study uses a service-dominant logic (SDL) approach as the basis for the study of value co-creation in the community. The nature of value co-creation research in community contexts shows strong relationships and engagement among community members to integrate resources that can go beyond individual motivation (Sawhney et al. 2005; Lacoste, 2016; Brodie et al. 2013). Engaged consumers exhibit enhanced consumer loyalty, satisfaction, empowerment, connection, and emotional bond (Brodie et al. 2013).

By optimizing the role of the engagement community, participants can dynamically interact and actively encourage resource integration between members in value co-creation activity as an application of the service-dominant logic (SDL) concept (Vargo \& Lusch, 2008; Vargo and Lusch, 2016; Leclercq and Poncin, 2016; Saarijärvi and Kuusela, 2013). Communities can become a forum for knowledge-sharing because the members generally have commitment and trust in their relationships for the success of service value delivery (Morgan and Hunt, 1994; Sumarlin et al. 2013). Previous studies on knowledge-sharing as a relationship in the community (Hung et al. 2013; Gummerus et al. 2017) used the value co-creation behavior model (Laud et al. 2015; Laud and Karpen, 2017). Thus, the community's relationship and participation can be part of the value cocreation behavior through the integration of consumer operant resources (knowledge and skill resources) (Pongsakornrungsilp, 2010).

Research on service-dominant logic (SDL) generally examines the role of the existence of a platform ecosystem for resource integration, which leads to marketing innovation, company performance, service innovation, business model development for company sustainability, or in virtual brand community context (Widjojo et al. 2019; Brodie et al. 2013; Romero and 
Molina, 2011; Lusch and Nambisan, 2015; Hung et al. 2013; Ercsey I, 2017). There is a research gap, as stated by Hung et al. (2013) that it is necessary to include the perceived benefit variable as an outcome of value cocreation activities. For this reason, the research includes the perceived benefit variable as a mediation between value co-creation activities (customer participation behavior and customer citizenship behavior) on loyalty to the community through the service-dominant logic (SDL) approach in the context of organic communities (Yi and Gong, 2013; Laud and Karpen, 2017; Gummerus et al. 2012; Gummerus et al. 2017; Kuo and Fang, 2013; Akman, 2016; Dholakia, 2009; Kang and Shin, 2016). It shows the application of servicedominant logic on the basic premise of usefulness and organizational involvement in value co-creation activities in accordance with membership behavior in organic product communities in Indonesia. This study uses service dominant logic concept with premise one (service is the fundamental basis of exchange), premise nine (all social and economic actors are resource integrators), premise ten (value is always uniquely and phenomenologically determined by the beneficiary), and premise eleven (value co-creation is coordinated through actor regenerated institutions and institutional arrangements) (Vargo and Lusch, 2016; Vargo and Lusch, 2017).

The nature of value co-creation activities in this study is to see the effect of the integration of operant resources (knowledge, skills, and experience) on perceived benefits and loyalty to the service community. Loyal community members have a strong relative and emotional attachment to product information services or services. Members loyal to the community have a strong relationship (relative attachment) and emotional attachment to the community or product information services (Dick and Basu, 1994). Thus, these members can be encouraged to reveal positive things about the community and engage in repeated or intensive participating behaviors (Dick and Basu, 1994). In addition, loyal community members can transmit information and knowledge about organic products to potential markets through word of mouth and invite other non-members to join the organic product consumer community (Lin, 2010).

Loyalty of consumer members is important to be known by the stakeholders of organic products, both by producers, organic farmers, and the government in conducting education or campaigns about the importance of organic consumption. Thus, it is hoped that the effectiveness of education, socialization, and campaigns of organic products to the wider community can be more easily echoed.

Unlike previous researches, this study is novel in that from the theoretical aspect, it is comprehensive. This study examines the perspective of the service dominant logic and service relationship theory. This research has the novelty of a specific and in-depth study of the value co-creation model that affects loyalty to the community. The study complements the studies of Yi and Gong (2013), Hung et al. (2013), and Laud and Karpen (2017) with different perspectives regarding the consequences of value co-creation behavior activities. This study complements the literature review of Yi and Gong (2013) and Yi et al. (2011) became an empirical study in the context of the consumer community of organic food products in Indonesia. This study follows up the study of Hung et al. (2013) by adding perceived benefits as the form of customer value proposition of value cocreation behavior outcomes (Alves et al. 2016). This study develops a new taxonomy of resilient community studies and community engagement as bonding and forum for sharing knowledge and information through the development of loyalty to community modelling (Lin et al. 2009, Lin, 2010, Kuo and Fang, 2013). This research also contributes through a different perspective, namely the development of value co-creation modelling in the context of the consumer community for services, not the brand community (Laud et al. 2015).

The study constructs a model of applying value cocreation behavior among community members with a service-dominant logic (SDL) approach by looking at the influence of customer participation and customer citizenship behavior on loyalty to the community mediated by the perceived benefit values. This research aims to analyze the effect of value co-creation behavior on the campaign about the importance of organic foodproducts consumption.

\section{METHODS}

To achieve the objectives of this research and to prove the aforesaid hypotheses, we have adopted quantitative research that adjusted all the items of measuring instruments from past literature. This study uses primary data as a data source. A Likert scale is used in measuring the level of agreement or disagreement 
of respondents with statements measuring an object. The data were collected from several communities in Jakarta, South Tangerang, and Bandung, between March to September 2020. Respondents were consumers of organic food products who were members of the consumer community, domiciled in Jakarta, Depok, Bogor, Tangerang, Bekasi (Jabodetabek), Bandung, and Yogyakarta. The community in this research is the consumers' community of organic food products. The respondents are community members who consume and have concerns for organic horticulture products and their processed products. This study examines members of the consumer community in consuming organic food. Generalization is possible if there are similarities in context specificity in the consumer community labelled organic, green, and healthy. The data and information gathering from the members of four organic communities, namely on Komunitas Selaras Alam, Komunitas 1000 Kebun, Komunitas Paprika Loca, and Komunitas Arista Montana. In this study, the population and samples are assumed as unknown due to the unavailability of official data on the number of organic product customer communities in these areas.

The sampling method in this study is a convenience sampling approach. Sampling in this study is conducted by direct personal approach. The questionnaire was delivered to community members on a self-managed basis where the Google questionnaire link was submitted via private chat or through a WhatsApp group with the permission of the community manager. The author obtained complete samples of 385 questionnaires from customers of organic food products to investigate the effects of value co-creation behavior on customers' loyalty to the community.

The construction model of this study is based on the development of hypotheses between the variables described above. The study uses Covariance-Bases Structural Equation Model (CB-SEM) to test the theory in the modelling that the researcher developed based on the value co-creation concept approach, which in turn is based on Service-Dominant Logic theory. Researchers tested the causal relationship between four latent variables: customer participation behavior, customer citizenship behavior, perceived benefits, and loyalty to the community, measuring the model and its suitability to empirical data. Data was analyzed by performing SEM with the help of IBM SPSS Amos 23 software.

The scale of measurement or questionnaires for customer participation behavior, customer citizenship behavior, perceived benefits, and loyalty to the community were developed from the instruments of previous researchers with the following explanations (Table 1).

Table 1. The measurement scale development

\begin{tabular}{lll}
\hline Latent Variables & Indicators & Sources \\
\hline Customer Participation Behavior & & \\
How the contribution of customer participation & Information seeking; & Laud \& Karpen (2017); Yi \& Gong \\
behavior that supports the process of integrating & Information sharing; & (2013); Yim et al. (2012); Yi et al. \\
resources in obtaining quality services (Yim et al. Responsible behaviour; & $(2011)$ \\
$2012)$ & Personal interaction &
\end{tabular}

\section{Customer Citizenship Behavior}

Service mechanisms and efforts to maintain Feedback; relationships with others in the belief that their Advocacy; actions will be beneficial over time (Anaza and Zhao Helping; 2013, Yi and Gong 2013).

\section{Perceived Benefit}

The consumers perceived benefits from value co- Social benefit; Informational creation behavior activities in a community (Dong et benefit; Emotional benefit al. 2014, Gummerus et al. 2012)

\section{Loyalty to the Community}

A positive attitude as a disposition for product information as the basis for repeat patronage to continue to participate, reinforces the behavioral intensity to continue consuming the product (Dick \& Basu 1994), as well as an encouraging attitude and community recommendations to others (Lin 2010).
Laud \& Karpen (2017); Yi \& Gong (2013), Anaza and Zhao, (2013); Yi et al. (2011)

Gummerus et al. (2017, Dong et al. (2014), Gummerus et al. (2012, Dholakia (2009), Nambisan and Baron (2007)

Behavioral Intention; Repeat Gummerus et al. (2017); Chen and $\mathrm{Hu}$ Patronage; Recommendation (2010); Lin (2010; Auh et al. (2007); to others

Dick\&Basu (1994). 
Variables of customer participation behavior and customer citizenship behavior were adapted from Yi \& Gong (2013) and Laud \& Karpen (2017). The indicators of customer participation behavior include information seeking (conscious effort, value experiences), information sharing (proper and clearly information), responsible behavior (being cooperative, obeying the rules and policies), and personal interactions (politeness, friendliness, courtesy) (Yi and Gong, 2013, Laud \& Karpen, 2017). On the other hand, customer citizenship behavior includes feedback (providing a valuable idea, experience sharing), advocacy (positive word of mouth, encouraging others of the organic products knowledge), helping (advice assist, problem-solving), and tolerance (willingness to be patient, understanding) (Yi and Gong 2013; Laud \& Karpen 2017).

Perceived benefit value indicators were adapted from Dong et al. (2014), Gummerus et al. (2012), Gummerus et al. (2017). Loyalty to community were adapted from Dick and Basu (1994) and Lin (2010). Perceived benefits are identified as the benefits consumers feel from participating in or appreciating the value co-creation process in a community (Dong et al. 2014, Gummerus et al. 2012). In this study, perceived benefits include social benefits, informational benefits, and emotional benefits (Gummerus et al. 2017; Dholakia, 2009; Nambisan \& Baron, 2009). Loyalty to community in this research includes behavioral intention, repeat patronage, and recommendation/encouragement to others (Dick \& Basu 1994; Auh et al. 2007; Lin, 2010; Gummerus et al. 2017). Based on the theory and previous studies, a framework of the research concept can be seen in Figure 1.

\section{Hypothesis Development}

\section{The Effects of Customer Participation Behavior and Customer Citizenship Behavior on Perceived Benefit}

Customer participation behavior and customer citizenship behavior apply the concept of value co-creation, which is based on the service-dominant logic (SDL) approach, to understand consumer relationships in the community (Yi and Gong, 2013; Laud and Karpen, 2017). Kuo and Feng (2013) confirmed the nature of research on the community, namely customer participation from value co-creation activities in the community, resulting in perceived benefits. Sihlman (2012) states that participation in the community affects the perceived benefits obtained from participating in various activities and connecting with the community in sharing values. In the context of organic communities, the variables of participation behavior and citizenship behavior are important variables that represent value co-creation activities from the exchange of knowledge resources, skills, and experiences about organic products. In addition, community members are expected to gain perceived social, informational, and emotional benefits in a sustainable manner over time by joining the community. The proposed hypotheses are:

H1: Customer Citizenship Behavior has a positive influence Perceived Benefit Value

H2: Customer Participation Behavior has a positive influence on Perceived Benefit Value

The Effects of Perceived Benefit Value on Loyalty to Community

The results of previous research indicated a positive influence between perceived benefits and consumer loyalty to the community (Gummerus et al. 2017, Gummerus et al. 2012; Kim et al. 2004; Shang et al. 2006; Kang and Shin, 2016). These findings are reinforced by the study by Kuo and Feng (2013), which found the correlation between benefits gained and community commitment. In the context of organic communities, community members who positively perceive benefits for organic communities are expected to continue to be loyal and continue to join and bond with the community. Loyal community members are expected to support forming a strong community in terms of campaigns and education on the benefits of organic products in the community. Thus, the proposed hypothesis is:

H3: Perceived Benefit Value has a positive influence on Loyalty to Community.

\section{RESULTS}

\section{Respondents' Demography}

The results of the demographic analysis of the study showed that from 385 respondents, 43.9 percent of respondents were male, and 56.1 percent of respondents were female. Respondents aged between 26-45 dominate at 60.5 percent. According to their formal education background, the respondents was dominated by undergraduates (S1/D4) as much as 45.2 percent. A total of 63.4 percent of respondents are married and most of the respondents are self-employed or pursue their career as entrepreneur (30.9 percent). 


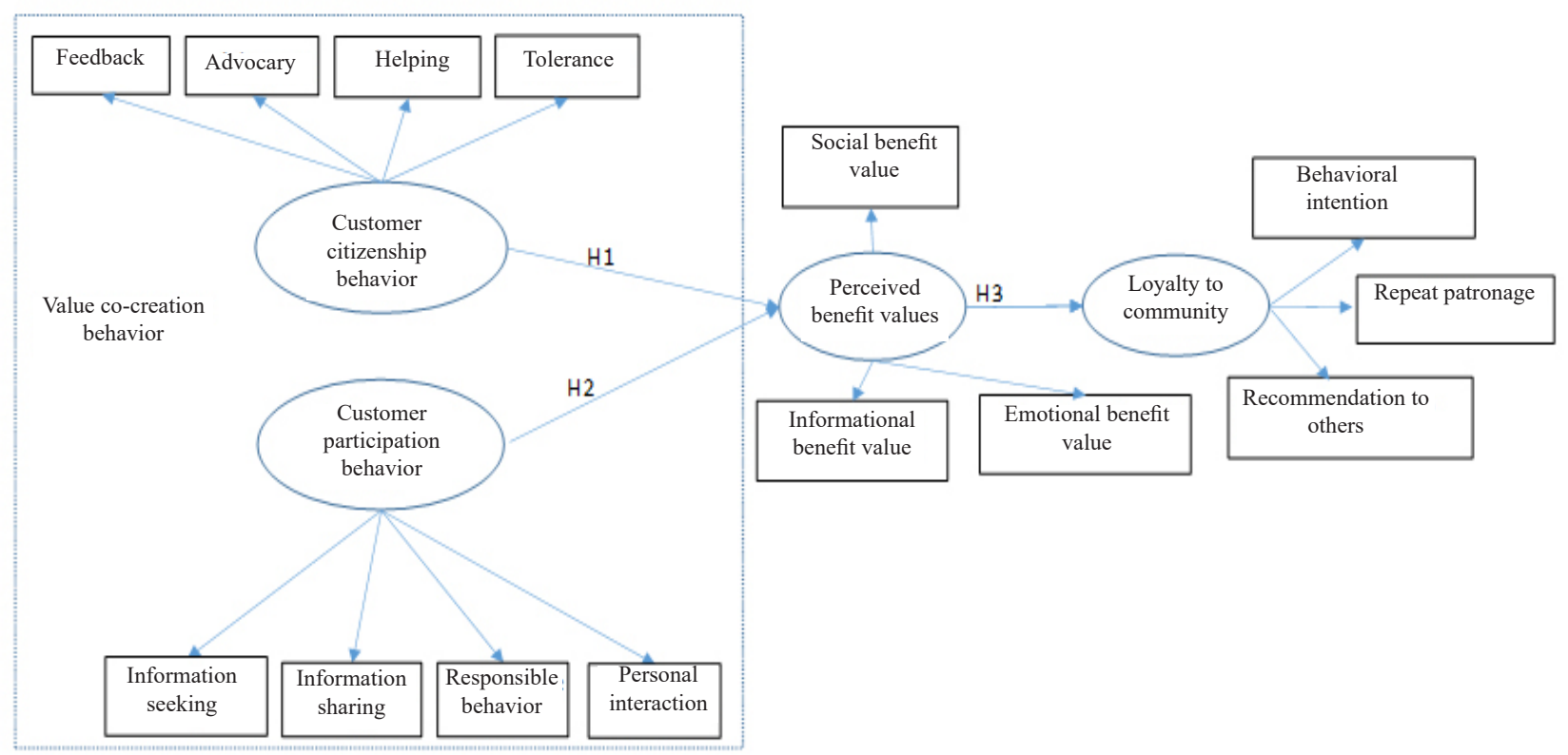

Figure 1. The research-development model of loyalty to the community based on value co-creation behavior (Yi\&Gong (2013), Laud\&Karpen (2017); Gummerus et al. (2012), Gummerus et al. (2017), Dick\&Basu (1994), Lin (2010), Auh et al. (2007)).

\section{Measurement Model Analysis Results}

Measurement model analysis is used to ensure that all indicators or observed variables meet the requirements. In other words, this step is performed to determine their validity and reliability. Table 2 shows the values of Average Variance Extracted (AVE), Cronbach alpha, and Composite Reliability for each construct. Based on the results shown in Table 2, it can be concluded that the validity of the convergence and internal consistency of measurements in this study is good. This is indicated by the AVE value for each construct, higher than 0.5 , which indicates that the convergence validity for each construct is good. Table 1 also shows that the value of Cronbach alpha and composite reliability of each construct exceeds 0.7 , which indicate that the measure used in this study is reliable (Hair et al. 2014). In this study, the method of reliability test used is a composite of reliability, it is better to estimate the internal consistency of a construct (Hair et al. 2014).

\section{Model Fit Test Results}

Table 3 shows the results of data processing regarding the measure of Goodness-of-Fit in the research model. Absolute fit measures the overall fit of the model (both the measurement model and the structural model) together (Tabachnick and Fidell, 2001; Hair et al. 2014). The absolute fit measures value shown by CMIN, CMIN/DF, GFI, and RMSEA in this study and gave varied results. The CMIN value of 3.166 is still categorized as good as it indicates that there is no significant difference between the unrestricted covariance and restricted covariance matrices. A low chi-square value with a significance level of less than 0.05 indicates that the actual input matrix is different from the predicted input matrix (Hair et al. 2014). In other words, the research model and the data used have little suitability. The value of CMIN/DF in the study is 1.583 which means good. The recommended CMIN/DF value is between one and two, which indicates that the model fits the data (Marsh and Hocevar, 1985). Thus, the research model is in accordance with the data used.

The GFI value in this study was 0.945 , greater than 0.9, which was the cut-off value. A high Goodness of Fit (GFI) value indicates that the model's ability to extract the empirical data variance is high (Amoli and Farhoomand, 1996). This shows that this research model can be properly applied in this study. The RMSEA value in the study was 0.062 . The goodness of fit can be expected when the model is estimated in the population. The recommended RMSEA value between 0.05 to 0.08 is an index for the acceptance of the model that shows a close fit of the model based on degrees of freedom (Hair et al. 2014). Thus, the RMSEA value generated in the study can be categorized as good (Tabachnick and Fidell, 2001). 
Table 2. Validity and reliability test

\begin{tabular}{lccc}
\hline Construct & AVE $(\mathrm{VE} \geq 0.50)$ & Cronbach alpha & Composite Reliability $(\mathrm{CR} \geq 0.70)$ \\
\hline Customer Participation Behavior & 0.561 & 0.881 & 0.898 \\
Customer Citizenship Behavior & 0.612 & 0.792 & 0.812 \\
Perceived Benefit Values & 0.670 & 0.847 & 0.913 \\
Loyalty & 0.582 & 0.776 & 0.888 \\
\hline
\end{tabular}

Table 3. The value of goodness of fit of the main empirical model

\begin{tabular}{llccc}
\hline Type of goodness of fit model & Index goodness of fit model & Cut-off Value & Result & Information \\
\hline Absolute fit measures & Chi square statistic $\left(\chi^{2}\right.$ atau CMIN) & Small & 3.166 & Good \\
& P & $>0.05$ & 0.000 & Bad \\
& GFI & $>0.90$ & 0.945 & Good \\
& RMSEA & $<0.08$ & 0.062 & Good \\
& Normed $\chi 2(\mathrm{CMIN} / \mathrm{DF})$ & $1<$ Normed $\chi 2<2$ & 1.583 & Good \\
Incremental fit measures & CFI & $>0.94$ & 0.909 & Good \\
Parsimonious fit measures & Adjusted Goodness of Fit Index (AGFI) & $>0.90$ & 0.924 & Good \\
\hline
\end{tabular}

Incremental fit measures the comparative of the proposed model with other models evaluated by the researcher (Tabachnick and Fidell, 2001; Hair et al. 2014). The value of incremental fit measures shown by CFI in this study is 0.960 which means it is a good fit. The recommended value is CFI $>0.9$ (Hooper et al. 2008). The CFI value is very good for measuring the level of acceptance of a model (Hooper et al. 2008). Thus, the research model can be well received. The parsimonious value of fit measures shown by AGFI in this study was 0.922 . The recommended value is if AGFI has a value equal to or greater than 0.9 (Hair et al. 2014). However, the AGFI value categorizes as good (Tabachnick and Fidell, 2001).

\section{Structural Model Fit Results}

Testing the structural model of this study was conducted to predict causality between latent variables to reveal the validity of the theoretical model built in this study through testing research hypotheses (Hair et al. 2010). Structural model testing is carried out by evaluating the path coefficient value and the $t$ statistical value or the Critical Ratio (CR) value for the significance test between constructs in the structural model (Anderson and Gerbing 1988; Hair et al. 2010). The assessment of the suitability of the structural model of the SEM structural analysis is presented in Table 4 and Figure 2.

Table 3 results from SEM estimation and hypothesis testing, which shows that three hypotheses are supported. This is because the value of Critical Ratio (CR) or $\mathrm{t}$ statistics $\mathrm{H} 1, \mathrm{H} 2$, and $\mathrm{H} 3$ are significant, having a CR value of more than 1.96. As is known, the recommended CR value in SEM analysis to show a good level of significance is more than 1.96 (Hair et al. 2014).

\section{The Influence of Customer Citizenship Behavior on Perceived Benefit Values (HI)}

The first hypothesis that Customer Citizenship Behavior (CCB) affects Perceived Benefit Value (PBV) in this study is supported. The results of data analysis show a significant $C R$ value $(C R=3.671)$ and a standardized estimation value of 0.206 (Table 3). This figure shows that $\mathrm{CCB}$ has a positive and significant effect on PBV. This shows that the higher the civic behavior, the more benefits are felt from the shared-value activities of members of the organic community. In other words, the more intense consumers carry out citizenship activities (giving feedback, advocacy, helping, and tolerance), the more perceived benefits consumers will obtain, both in terms of social value, informational value, and emotional value. The results of this study are in line with Ercsey's research (2017) which found that factors of customers' citizenship behavior as a manifestation of value co-creation activities have a significant effect on perceived benefit value. This study is also in line with the findings of Laud and Karpen (2017), Akman (2016), and Alves et al. (2016) where value co-creation behavior (participation behavior and citizenship behavior) has a positive effect on outcome values. 
Table 4. Research hypothesis test: structural parameter estimation

\begin{tabular}{|c|c|c|c|c|}
\hline Hypothesis & Path Coefficients & t-value & p-value & Results \\
\hline H1: Customer & 0.206 & $3.671 * * *$ & 0.000276 & port \\
\hline H2: Customer Participation Behavior $\rightarrow$ Perceived & 0.183 & $3.260 * *$ & 0.001214 & port \\
\hline H3: Perceived Benefit Value $\rightarrow$ Loyalty to Community & 0.404 & $7.629 * * *$ & 0.00001 & Support \\
\hline
\end{tabular}

Notes: ${ }^{* * *}$. The correlation was significant at the 0.001 level (2-tailed); ${ }^{* *}$. The correlation is significant at the 0.05 level (2-tailed)

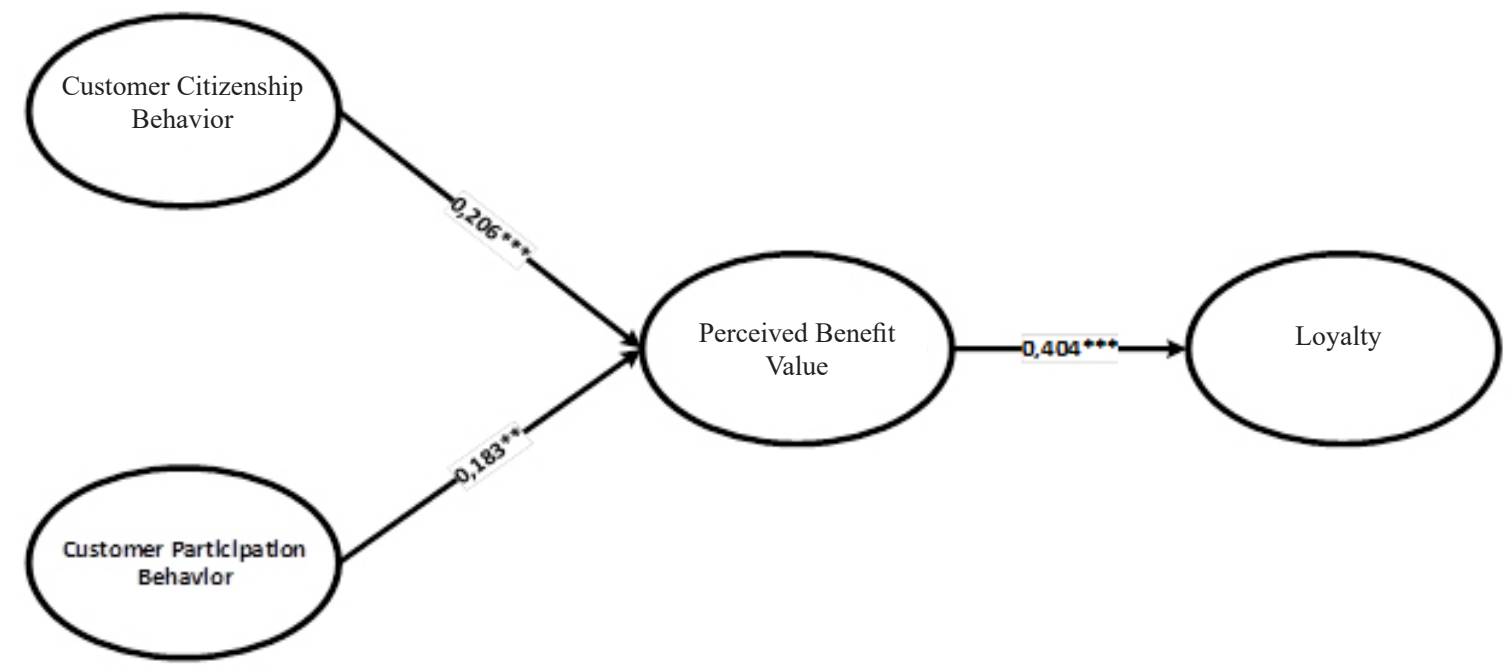

Figure 2. Structural model test results $(* * *$ The correlation is significant at the 0.001 level (2-tailed); **. The correlation is significant at the 0.05 level (2-tailed); $2=3.166 ; \mathrm{CMIN} / \mathrm{DF}=1.583 ; \mathrm{GFI}=0.945$; AGFI $=0.924 ; \mathrm{RMR}=0.052 ; \mathrm{RMSEA}=0.062 ; \mathrm{NFI}=0.807$; $\mathrm{CFI}=0.909$ ).

The results of observations revealed the actual condition of the organic consumer community. There is a friendly atmosphere where members like to ask about their health problems or their family for example, asking about cases of comorbid disease. Other members or community managers voluntarily provide information or experiences related to it, such as giving input for handling, lifestyle, or consumption of foods that improve conditions. The behavior of helping, giving advice, tolerance, and providing feedback on these questions and problems makes members feel the perceived benefit.

From the explanation of the definition of customer citizenship behavior as Service mechanisms and efforts to maintain relationships with others in the belief that their actions will be beneficial over time. Therefore, the hypothesis $1(\mathrm{H} 1)$ test result is the reflection of the application of service dominant logic in foundation premise 1 (FP1), namely, service is the fundamental basis of exchange. The result of this hypothesis test also strengthens the application of the concept of service-dominant logic on the premise of value benefits and organizational involvement in value co-creation activities in the consumer community of organic food products in Indonesia. Namely the application of the foundation premise 6 (FP6) of service dominant-logic which focuses on the beneficial outcomes, also the foundation premise 8 (FP8) in the form of a relational orientation of usefulness in dialogue, participation, and engagement activities as service-centered. In addition, it is also a reflection of the foundation premise 10 (FP10) of the service dominant logic in the form of unique and phenomenal benefit values from operant resources (Vargo and Lusch 2016).

The Influence of Customer Participation Behavior on Perceived Benefit Values (H2)

The second hypothesis that Customer Participation Behavior (CPB) affects Perceived Benefit Value (PBV) in this study is supported. The results of data analysis showed a significant $\mathrm{CR}$ value $\left(\mathrm{CR}=3.260^{* *}\right)$ and a standard estimate value of 0.183 (see Table 3). The test results show that the variable customer participation behavior has a significant positive correlation with 
perceived benefit values. This shows that the higher the behavior of participating (information seeking, information sharing, responsible behavior, personal interaction) in the community, the perceived benefit values of organic community members will increase. This is in line with Kuo and Feng (2013), Sihlman (2012), Ercsey (2017), Alves (2016), Laud and Karpen (2017, Akman (2016), and Alves et al. (2016) who found that the customer participation relationship from the value co-creation behavior process in the community had a significant positive effect on perceived benefits values.

The results of observations in the consumer community of organic food products from this study indicate that most community members like community activities that share information about the benefits and organic lifestyles. They even follow up by following social media accounts such as IG, podcasts, Facebook from community managers and actively and passively receiving information submitted by community managers.

Based on the meaning of customer participation behavior, namely how the contribution of customer participation behavior that supports the process of integrating resources in obtaining quality services (Yim et al. 2012). Therefore, the results of this hypothesis test strengthen the application of the foundation premise 8 (FP8) in the form of a relational orientation of usefulness in dialogue, participation, and engagement activities as service centered. This is also reflecting the foundation premise 6 (FP6) of service dominant-logic which focuses on the beneficial outcomes. In addition, it is also a reflection of the foundation premise 10 (FP10) of the service dominant logic in the form of unique and phenomenal benefit values from operant resources (Vargo and Lusch, 2016).

\section{The Influence of Perceived Benefit Values on Loyalty to Community (H3)}

The third hypothesis that Perceived Benefit Value (PBV) affects Loyalty to Community (LC) in this study is supported. The results of data analysis showed a significant $\mathrm{CR}$ value $\left(\mathrm{CR}=7.629^{* *}\right)$ and a standard estimate value of 0.00001 (see Table 3). The results of the influence test show that the perceived benefit values variable has a significant positive effect on loyalty to community. This shows that the higher the perceived benefit values obtained by organic community members, the loyalty to the community will increase. The result of this study is in line with Kang and Shin (2016) which states that there is a significant positive influence of consumers' perceived benefits (functional, experiential, and symbolic) on virtual brand community loyalty. This study is also in line with Chen and $\mathrm{Hu}$ (2010) where perceived value has a strong influence on customer loyalty at coffee outlets.

From the observations, loyal members feel the benefits of being members of an organic community because members are usually given the knowledge and confidence to be healthy without being expensive, organic heart and organic mind), not just eating organic. Members are given an understanding of a healthy lifestyle through regular bi-weekly discussion sessions.

This study proves that a strong members community engagement based on the value co-creation behavior involves the perceived benefit from the customer participation behavior and citizenship. This becomes a form of bonding and forum for sharing knowledge and information that forms the basis for developing loyalty to the community (Lin et al. 2009; Lin 2010; Kuo and Fang, 2013). This means that the third hypothesis result shows the application of the service dominantlogic in foundation premis 11 (FP11) where value cocreation is coordinated by actors through institutional arrangements (Vargo and Lusch, 2016).

\section{Managerial Implications}

This study provides managerial implications in increasing public knowledge to consume organic products in Indonesia through the loyalty of the organic product consumer community members. Loyal members are a captive market because they are consumers of organic products educated and understand the benefits of organic products for health and the environment. The government and all stakeholders of organic products need to work together by empowering the community's role as a media for information dissemination campaigns and increasing awareness of organic consumption more broadly.

In the future, organic business players need to develop more marketing innovations by involving the community, namely by implementing community-based marketing. Meanwhile, organic producers and organic farmers need to join the community to implement the concept of community-based agriculture. 


\section{CONCLUSIONS AND RECOMMENDATIONS}

\section{Conclusions}

The research on loyalty to community-based value cocreation behavior investigated 4 variables. Customer citizenship behavior and customer participation were exogenous variables. Perceived benefit value and loyalty to the community were mediating and endogenous variables, respectively. Specifically, this research examined customer citizenship behavior, customer participation behavior on perceived benefit value, and loyalty to the community. This was carried out by quantitative analysis using a Structural Equation Model (SEM) with SPSS and AMOS software for data analysis. Using a sample of population 395 respondents, the study showed that the customer citizenship variable while conducting value co-creation behavior had a significant and positive effect on loyalty to the community through perceived benefit value. Consumers present feedback, advocacy, helping, and tolerance among members to maintain the relationship with each other. Customer participation behavior while conducting value co-creation behavior is significantly and positively effect on loyalty to community through perceived benefit value. The consumers present services such as the clarification and proper information of organic products in conducting operant integration resources and personal interaction among members. The results also show that the value cocreation behavior (customer citizenship behavior and customer participation behavior) adopted from $\mathrm{Yi}$ and Gong (2013) had developed in different perspective and culture in this study. This means customer value co-creation behavior had developed within a more comprehensive model that integrates relationship marketing theoretically related loyalty and perceived benefit value constructs.

\section{Recommendations}

Community managers need to develop a resilient community by emphasizing customer citizenship behavior and customer participation as value co-creation activities. This is because value co-creation behavior has been shown to significantly affect loyalty to the community through customers' perceived benefits. In addition, community managers need to pay attention to the value of perceived benefits because it has been proven to strengthen member loyalty to the community. Community managers also need to increase efforts to create member loyalty because loyal members will spread information, knowledge, consumer experiences, and organic lifestyles to their families and close people and their relationship by word of mouth. Future research should test within a more comprehensive model that integrates other theoretically related constructs. For example, additional consequences (e.g., return on equity, sales, and consumption) of customer value cocreation behavior should receive more attention. Future research also can examine the role of moderators such as customer personality and relationship age. This study focuses on value co-creation behavior from the customer's point of view. However, value creation is a collaborative work between customers and employees. Further research can examine value co-creation behavior from the employee's point of view. The number of the communities (4 in all) used in the scale is rather small. Studies involving bigger sample population would provide more comprehensive literatures to researchers.

\section{REFERENCES}

Akman HM. 2016. Value co-creation in online collaborative communities: exploring the drivers and outcomes of value co-creation activities from the individual community member point of view [Dissertation]. The University of Adelaide Business School.

Alves H, Ferreira JJ, Fernandes CI. 2016. Customer's operant resources effects on co-creation activities. Journal of Innovation \& Knowledge 1(2): 69-80. https://doi.org/10.1016/j.jik.2016.03.001.

Amoli JE, Farhoomand AF. 1996. A structural model of end user computing satisfaction and user performance. Information \& Management Research 30(1996): 65-73.

Anaza NA. Zhao J. 2013. Encounter-based antecedents of e-customer citizenship behaviors. Journal of Services Marketing 27(2): 130-140.

Anderson JC, Gerbing DW. 1988. Structural equation modeling in practice: A review and recommended two-step approach. Psychological Bulletin 103(3): 411-423. https://doi.org/10.1037/00332909.103.3.411.

Auh S. et al. 2007. Co-production and customer loyalty in financial services. Journal of Retailing 83(3): 359-370. $\quad$ https://doi.org/10.1016/j. jretai.2007.03.001

Brodie RJ. et al. 2013. Consumer engagement in a virtual brand community: An exploratory 
analysis. Journal of Business Research. https:// doi.org/10.1016/j.jbusres.2011.07.029.

Chrysanthini B, Sumarwan U, Rifin A. 2017. Preferensi konsumen terhadap produk sayuran organik (Studi kasus konsumen UD Fabela-Myfarm) di Bogor Jawa Barat. Manajemen IKM IPB 12 (2): 151-160.

Chen PT, Hu HH. 2010. The effect of relational benefits on perceived value in relation to customer loyalty: an empirical study in the Australian coffee outlets industry. International Journal of Hospitality Management 29(3): 405-412. https://doi.org/10.1016/j.ijhm.2009.09.006.

Dholakia UM, Blazevic V, Wiertz C, Algesheimer R. 2009. Communal service delivery: How customers benefit from Participation in Firmhosted virtual P3 communities. Journal of Service Research 12 (2): 208-226.

Dick AS, Basu K. 1994. Customer loyalty: toward an integrated conceptual framework. Journal of the Academy of Marketing Science 22(2): 99-113.

Dong B, Sivakumar K, Evans KR, Zou S. 2014. Effect of customer participation on service outcomes: the moderating role of participation readiness. Journal of Service Research 18(2): 1-17. https:// doi.org/10.1177/1094670514551727.

Ercsey I. 2017. The role of customers' involvement in value co-creation behaviour is value co-creation the source of competitive advantage? Journal of Competitiveness. 9(3): 51-66.

Gummerus J. et al. 2012. Customer engagement in a facebook brand community. Management Research Review 35(9): 857-877. https://doi. org/10.1108/01409171211256578.

Gummerus J, Liljnder V, Sihlman R. 2017. Do ethical social media communities pay off? an exploratory study of the ability of facebook ethical communities to strengthen consumers' ethical consumption behavior. Journal of Business Ethics. Springer Netherlands. 144(3): 449-465. https://doi.org/10.1007/s10551-0152830-y.

Hair JF. et al. 2014. Multivariate Data Analysis. 7th edn. Edinburgh Gate. Pearson Education Limited. https://doi.org/10.1111/j.1467-9574. 1962.tb01184. x.

Hair JF, Black W, Babin BJ, Anderson RE. 2010. Multivariate data analysis: a global perspective. March Edition: Seventh Edition Publisher: Pearson.

Hubeis M, Widyastuti H, Wijaya NH. 2015. Prospek pangan organik bernilai tambah tinggi berbasis petani. Bogor: IPB Press.

Hung SW, Lin JZ, Chen PC. 2013. How social capital influences health community members' adoption of organic foods. British Food Journal 115(11): 1564-1582. https://doi.org/10.1108/BFJ-122011-0303.

Kang MA, Shin DH. 2016. The effect of customers' perceived benefits on virtual brand community loyalty. Online Information Review 40(3): 298-315. https://doi.org/10.1108/OIR-09-20150300.

Khorniawati M. 2014. Produk pertanian organik di Indonesia: tinjauan atas preferensi konsumen indonesia terhadap produk pertanian organik lokal. Jurnal Studi Manajemen 8(2): 171-182.

Kim WG, Lee C, Hiemstra SJ. 2004. Effects of an online virtual community on customer loyalty and travel product purchases. Tourism Management 25(3):343-355. https://doi.org/10.1016/S02615177(03)00142-0.

Kuo YF and Feng LH. 2013. Relationships among community interaction characteristics, perceived benefits, community commitment, and oppositional brand loyalty in online brand communities. International Journal of Information Management Elsevier Ltd. 33(6): 948-962. https://doi.org/10.1016/j. ijinfomgt.2013.08.005.

Lacoste S. 2016. Sustainable value co-creation in business networks. Industrial Marketing Management 52:151-162. https://doi. org/10.1016/j.indmarman.2015.05.018.

Laud G, Karpen IO. 2017. Value co-creation behaviour role of embeddedness and outcome considerations. Journal of Service Theory and Practice. 27(4): 778-807. https://doi. org/10.1108/JSTP-04-2016-0069.

Laud G, Karpen IO, Mulye R, Rahman K. 2015. The role of embeddedness for resource integration: Complementing S-D logic research through a social capital perspective. Marketing Theory. 15(4): 1-35. https://doi. org/10.1177/1470593115572671.

Leclercq T, Poncin I. 2016. Ten years of value cocreation: An integrative review. Recherche et Applications en Marketing. 1-35. https://doi. org/ 10.1177/2051570716650172.

Lin CP. 2010. Learning virtual community loyalty behavior from a perspective of social cognitive theory. International Journal of Human- 
Computer Interaction. 26(4): 345-360. https:// doi.org/ 10.1080/10447310903575481.

Lusch RF, Nambisan S. 2015. Service innovation: a service-dominant logic perspective. MIS Quarterly. 39(1): 155-175. https://doi. org/10.25300/MISQ/2015/39.1.07.

Mayrowani H. 2012. The development of organic agriculture in Indonesia. Forum Penelitian Agro Ekonomi 30 (2): 91-108.

Marsh HW, Hocevar D. 1985. Application of confirmatory factory analysis to the study of selfconcept: first- and higher-order factor models and their invariance across groups. Psychological Bulletin 97(3): 562-582.

Morgan RM and Hunt SD. 1994. The commitmenttrust theory of relationship marketing. Journal of Marketing 58 (Juli): 20-38.

MuzayanahFN, SurosoAI, Najib M.2015. Faktor-faktor yang memengaruhi resistensi pembelian pangan organik dan proses pendidikan konsumen. Jurnal Manajemen \& Agribisnis 12(3): 163-173.

Najib M, Sumarwan U, Septiani S. 2020. Organic food market in Java and Bali: Consumer profile and marketing channel analysis. Buletin Ilmiah Litbang Perdagangan 14 (2): 283-304.

Nambisan S, Baron RA. 2009. Virtual customer environments: testing a model of voluntary participation in value co-creation activities. Journal of Product Innovation Management 26(4): 388-406. https://doi.org/10.1111/j.15405885.2009 .00667$.

Nurhidayati et al. 2008. E-Book pertanian organik: suatu kajian sistem pertanian terpadu dan berkelanjutan integrated. Universitas Islam Malang. Program Studi Agroteknologi.

Noorjannah S. 2012. Koordinasi pengembangan sayuran organik: pengembangan pangan organik di Indonesia dan institusi pendukung. http:// ditsayur.hortikultura.deptan.go.id/index.php

Pongsakornrungsilp S. 2010. Value co-creation process : reconciling SD logic of marketing and consumer culture theory within the co-consuming group submitted by siwarit pongsakornrungsilp to the university of Exeter as a thesis for the degree. pp. 1-258.

Romero D, Molina A. 2011. Collaborative networked organisations and customer communities. Value co-creation and co-innovation in the networking era. Production Planning and Control 224: 1-22. https://doi.org/10.1080/09537287.2010.536619.

Saarijärvi HPK and Kuusela KH. 2013. Value co- creation: theoretical approaches and practical implications. European Business Review 25(1): 6-19.

SawhneyMV,VeronaG,PrandelliE.2005.Collaborating to create: The internet as a platform dor customer engagement in product inovation. Journal of Interactive Marketing 19(4(Autumn)): 1-15. https://doi.org/10.1002/dirario.

Shang RA, Chen YC, Liao HJ. 2006. The value of participation in virtual consumer communities on brand loyalty. Internet Research 16(4): 398-418. https://doi.org/10.1108/10662240610690025.

Sihlman R. 2012. The perceived benefits of online community participation and their effect on consumer commitment to ethical consumption. [Thesis]. Hanken School of Economics.

Slamet A, Nakayasu A, Bai H. 2016. The determinants of organic vegetable purchasing in jabodetabek region, Indonesia. Foods 5(85): 1-18. https:// doi.org/ 10.3390/foods5040085.

Sulaeman A. in Astuti et al. 2016. Pengembangan Pertanian Organik di Indonesia. Dewan Guru Besar IPB. Bogor: IPB Press.

Sumarlin AW, Agus WS, Budi S, Heny KD. 2013. Pengaruh wadah berbagi pengetahuan terhadap komitmen dari komunitas merk. Jurnal Manajemen Teknologi 12(1): 88-101.

Tabachnick BG, Fidell LS. 2019. Using multivariate statistics. Boston: Pearson.

Vargo SL, Lusch RF. 2008. Service-dominant logic: Continuing the evolution. Journal of the Academy of Marketing Science 36(1): 1-10. https://doi. org/10.1007/s11747-007-0069-6.

Vargo SL. and Lusch RF. 2016. Institutions and axioms: an extension and update of service-dominant logic. Journal of the Academy of Marketing Science 44(1): 5-23. https://doi.org/10.1007/ s11747-015-0456-3.

Vargo SL, Lusch RF. 2017. Service-dominant logic 2025. International Journal of Research in Marketing 34(1): 46-67. https://doi. org/10.1016/j.ijresmar.2016.11.001.

Widjojo H, Fontana A, Gayatri G, Soehadi AW. 2019. Value co-creation for innovation: evidence from indonesian organic community. Asia Pacific Journal of Marketing and Logistics. 1-35.

Willer H, Trávníček J, Meier C, Schlatter B. (Eds.) 2021. The World of organic agriculture. statistics and emerging trends 2021. Research Institute of Organic Agriculture FiBL. Frick. and IFOAM Organics International. Bonn (v20210301). 
Yim CK. (Bennett), Chan KW, Lam SSK. 2012. Do customers and employees enjoy service participation? synergistic effects of self and other-efficacy. Journal of Marketing 76(6): 121-140

Yi Y, Gong T. 2013. Customer value co-creation behavior: scale development and validation. Journal of Business Research. Elsevier Inc.
66(9): 1279-1284. https://doi.org/10.1016/j. jbusres.2012.02.026.

Yi Y, Nataraajan R, Gong T. 2011. Customer participation and citizenship behavioral influencesonemployeeperformance, satisfaction, commitment, and turnover intention. Journal of Business Research. Elsevier Inc 64(1): 87-95. https://doi.org/10.1016/j.jbusres.2009.12.007. 